\title{
James Neal receives ACRL's highest honor
}

James G. Neal, director of libraries at Johns Hopkins University, Baltimore, has been named the 1997 ACRL Academic/ Research Librarian of the Year. Neal will receive the award $(\$ 3,000$ and a citation) at a reception given in his honor on June 30, 1997 , 4:30-6:00 p.m., at the ALA Annual Conference in San Francisco. Baker \& Taylor Books sponsors the reception and donates the cash award and citation.

In nominating Neal, his colleagues said, "Neal is committed to cutting edge exploration as vital to

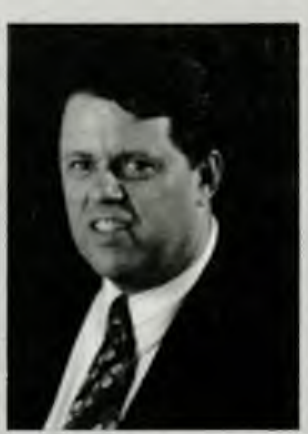

James G. Neal of Notre Dame; and social sciences librarian at Queensborough Community College, City College of New York (1973-76).

A colleague who worked with Neal while he was at Indiana University said, "Neal's work in Indiana can serve as a wonderful example of how he operates. He has won the highest award of the Indiana Library Federation for leadership in creating a statewide network, providing recognized leadership at the last White House Conference, working with legislative issues, and leading Indiana librarians into a defined vision of their future."

Neal was also cited for his involvement in a wide range of professional organizations. Within ALA he is currently a member of the ALA Executive Board (1994-2000) and the Planning and Budget Assembly (1995-97) and is cochair of the LITA/LAMA National Conference Networking/Technology Subcommittee and a member of the LITA/LAMA National Conference Steering Committee (1994-97). He has also served on ACRL's CERL Editorial Board (1990-96), LAMA's Executive Committee (1991-94), and ALA's International Relations Committee (1990-94). Outside ALA he has held positions of leadership in the Association of Research Libraries, the Coalition for Networked Information, the Committee on Institutional Cooperation, and the International Federation of Library Associations.

The Academic/Research Librarian of the Year Award is given annually to recognize an individual who is making an outstanding contribution to academic or research librarianship and library development. Previous winners include: Ralph Russell (1996), Joseph Boissé (1995), Irene B. Hoadley (1994), William A. Moffett (1993), and Carla Stoffle (1992).

To receive information on the ACRL Academic/Research Librarian of the Year Award contact Jack Briody, ACRL/ALA, 50 E. Huron St., Chicago, IL 60611-2795; (800) 545-2433, ext. 2516 or e-mail: jbriody@ala.org. The nomination procedures for all ACRL awards are available online at http://www.ala.org/acrl/ award2.html.-Jack Briody, ACRL ment (1979-81), and head of the College Lbrary Department (1977-79) at the University 